A孔」凹02 80879? NBSIR 88.3789

May 26, 1988

\section{CELL CONTROLLER OPERATIONS MANUAL}

By:

Bruce H. Thomas:
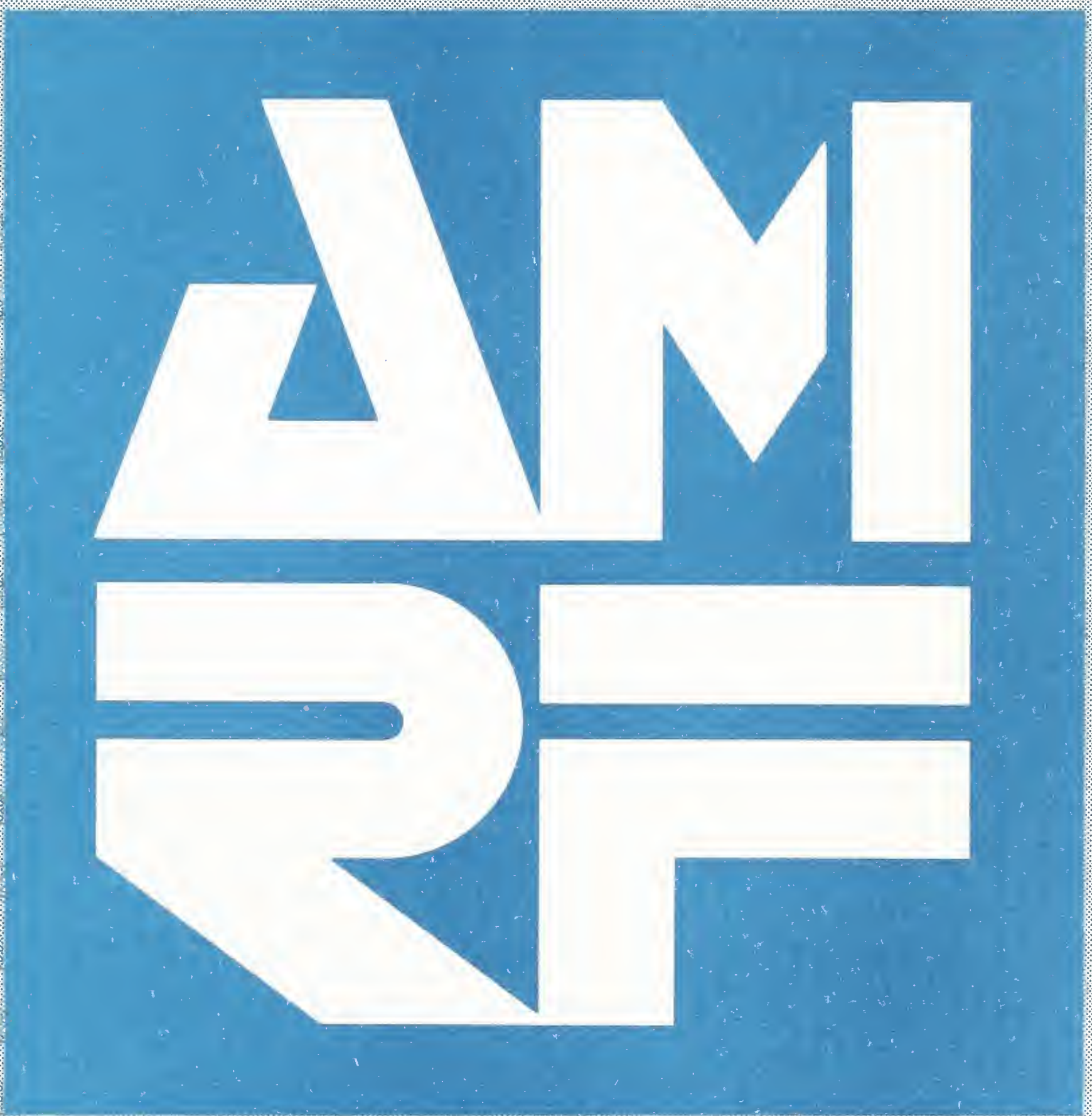

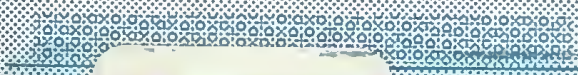

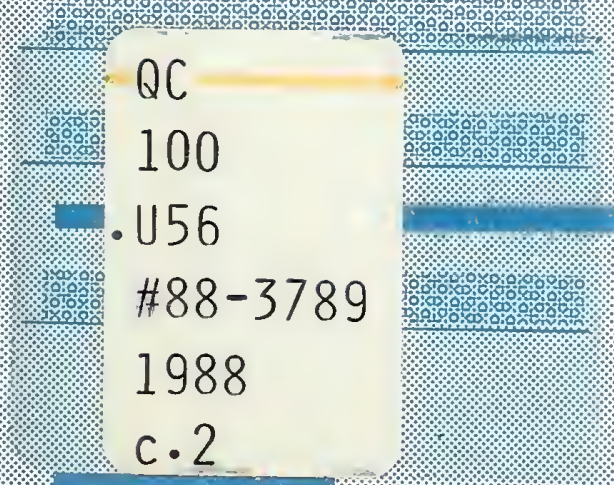



CELI CONTROLLER OPERATIONS MANUAL

Bruce Hunter Thomas

Certain commercial equipment, instruments, or materials are identified in this paper in order to adequately specify the experimental procedure. Such identification does not imply recommendation or endorsement by the National Bureau of Standards, nor does it imply that the materials or equipment identified are necessarily the best available for the purpose.

This Publication was prepared by United States Government employees as part of their official duties and is, therefore, a work of the U. S. Government and not subject to copyright. 

TABLE OF CONTENTS

I INTRODUCTION

II OPERATION OF THE SCREENS

III STARTUP

- $i$ CELL STARTUP

- 2 UNA PROTOCOL TO WORKSTATIONS $\cdot$. . . . . 3

IV OPERATION OF THE CELL

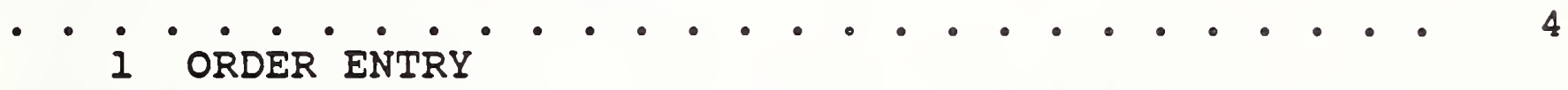

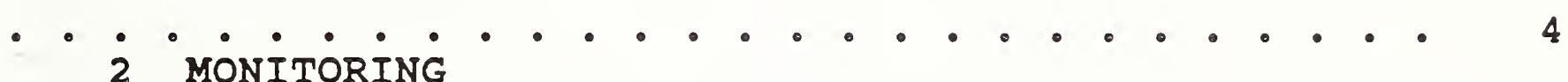

. . . . . . . . . . . . . . . . . . 5

$\mathrm{V}$ SHUTDOWN

5

APPENDIX FIGURES OF CELL SCREENS

. . . . . . . . . . . . . . . . . . . .

7 


\section{INTRODUCTION}

This manual is one in a series of operations manuals written to instruct a novice in the operation of one of the systems in the Automated Manufacturing Research Facility (AMRF) at the National Bureau of Standards. The manual assumes that the operator has some training in the use of the computer but little knowledge of the AMRF and only wants to operate the specific system in a standard configuration, not learn how or why it operates as it does. A reader interested in further information about the system should consult this document's bibliography for a list of other publications on the subject.

The AMRF, the major national laboratory for research in automated manufacturing, consists of six workstations and the control rooms and computer equipment necessary to operate them. The facility is a test bed where scientists and engineers from industry, academia, and the government work together on projects of mutual interest. Their research concentrates on the interfaces and measurement techniques needed for successful computer integrated manufacturing.

This particular manual addresses the operation of the AMRF's cell controller. The cell controller is currently the highest level controller in the AMRF. The cell controller directs the actions of five subordinate workstations: Vertical Workstation (VWS), Horizontal Workstation (HWS), Inspection Workstation (IWS), Material Handling Workstation (MHS), and Cleaning and Deburring Workstation (CDWS). There are four major sections to this manual, basic operation of the cell screen management system, startup of the cell, operation of the cell, and shutdown of the cell.

The cell controller is located in control Room 2 on the desk facing the window. The cell controller is running on a COMPAQ deskpro 386 computer, and requires software to be running concurrently on the sun Network computer. The sun computer is located on the table to left of the COMPAQ 386 , as you face the COMPAQ.

\section{OPERATION OF THE SCREENS}

The cell's screens are broken down into three major areas: menu area, data area, and the status bar. Figure 1 shows the location of the three areas on the screen. 


\section{Figure 1. Cell Screen Area}

Most user interaction with the system is directed through the menu area. The menu area occupies the topmost three lines on the monitor screen. The first line displays the name of the menu that the user has currently selected. The second line provides selection operations or data that may be chosen by the user. Left and right cursor control keys move the highlighting bar over the possible selections. The cursor control, or "arrow", keys are located on the number key pad on the right side of the keyboard. Pressing the ENTER key makes a selection which will cause an associated menu function to be called and/or another level of descent in the menu structure to occur. Pressing the ESCAPE key causes the user to back up a level in the menu structure. Function keys provide the user with direct access to many functions and screens, which are listed below. The third line displays the next level of options with the selection that is currently highlighted on line 2 .

\section{Function keys:}

FI: Not used

F2: Move from menu to data area 
F3: Communication state data display

F4: Mailbox display

F5: Cell control command display

F6: Cell control status display

F7: Summary display

F8: Work elements display

F9: Communication display

F10: Subordinate controller

Most of the information about the cell is presented in the second area on the screen, the data page. The data page covers from line 4 to line 24 on the screen. Many different page formats are defined which provide control and communications information to the user in real-time.

The last area on the screen, the status bar, provides summary or diagnostic information. The highlighted status bar displays the current clock cycle, the current screen identifier, communications status, and the current time. It provides constant feedback to the user that the cell is operating correctly. The current clock cycle should be updating about ten times a second. If the clock cycles have stopped updating for more than a few seconds, the system might have abnormally stopped. When the system has abnormally stopped, the computer must be turned off and then turned on. The computer is then rebooted, and the startup procedure is repeated.

III. STARTUP

\section{CELI CONTROLLER STARTUP}

1) The Sun MHS and CEII communications processes are started by either the Network operator or the AMRF operator.

2) Check that the power strip is connected to the COMPAQ 386 and there is no diskette in the disk drive. Check that the computer's power switch is on. When the COMPAQ 386 is ready to operate, the prompt

$$
\text { C> }
$$

will be the last item written on the screen.

3) To start the cell controller on the COMPAQ 386 enter commands

$$
\begin{aligned}
& \text { c: } \\
& \text { cd cell } \\
& \text { cell }
\end{aligned}
$$


See Figure 2 in the Appendix. The figures of the cell screens are to help users determine if their keyboard actions are producing the desired effects. The cell takes a few seconds to startup; therefore wait until clock cycles start updating before proceeding.

4) Using the arrow keys, highlight the menu option SET_COMM. Press the Enter key. See Figure 3 .

5) Using the arrow keys, highlight the menu option COMM_SWITCH. Press the Enter key. See Figure 4.

6) Using the arrow keys, highlight the menu option oN. Press the Enter key. See Figure 5. (Observe on the status bar the COMM: status should be switching from IDLE to RCV about every ten seconds.) This activates communication between the cell computer and the sun that provides a connection to the AMRF Network.

7) Enter the Esc key to return to the SET_COMM menu.

8) Enter the Esc key again to return to the main menu, CELI.

2. UNIVERSITY OF VIRGINIA (UVA) PROTOCOL TO WORKSTATIONS

9) Enter the F7 function key to bring up the summary display. See Figure 6 .

10) Using the arrow keys, highlight the menu option SET_CMDS. Press the Enter key. See Figure 7.

11) For each subordinate workstation that is being used, perform the next 6 steps on each workstation. An example of initializing the cleaning and Deburring Workstation is shown.

12) Using the arrow keys, highlight the menu option for the workstation desired (for this example use CDWS). Press the Enter key. See Figure 8.

13) Using the arrow keys, highlight the menu option sYNC. Press the Enter key. See Figure 9.

14) Wait for the workstation to return a SHUTDOWN status. See Figure 10.

15) Using the arrow keys, highlight the menu option WARM。 Press the Enter key. See Figure 11.

16) Wait for the workstation to return a READY status. See Figure 12 . 
17) Enter the ESC key to return to the SET_CMDS menu.

18) If there are more subordinate workstations to be initialized, repeat steps 12 through 19 for each workstation.

19) Enter the Esc key, and this will return to the main menu.

20) The cell controller is now fully operational.

IV. OPERATION OF THE CELL

There are two main operations the cell can perform, entering orders and monitoring.

1. ORDER ENTRY

To enter an order do the following.

1) While in the main menu CELI, use the arrow keys to highlight the menu option ORDERS and press the Enter key. see Figure 13.

2) Using the arrow keys, highlight the menu option ENTRY. Press the Enter key. See Figure 14. (The list of orders in the figure is an example of a possible screen.)

3) To select an order use the up and down arrows to highlight the desired order. Once the correct order has been highlighted, press the Enter key. The cell will acknowledge by displaying the message ORDER ACCEPTED, see Figure 15.

4) To enter another order repeat step 3.

5) If there are no more orders to select, press the Esc key. The menu area for the ORDERS screen will return, see Figure 16 .

6) Press the EsC key and the main menu CELI will return.

7) To enter more orders in the future return to the ORDER ENTRY screen and repeat steps 2 through 4.

\section{MONITORING}

The second operation of the cell is to monitor the status messages of the subordinate workstations. This monitoring is displayed on the summary screen. To bring up the summary screen enter the function key F7. An example of the summary screen is shown in Figure 17. The summary screen shows the commands being sent to the subordinate workstations and the 
status of the workstation. In this example, the Inspection Workstation was given a work order to receive a tray with a lot type of MIXED and quantity of four items in the lot. The Material Handling Workstation is in a READY state.

\section{SHUTDOWN}

1) Return to the main menu CELL by entering the Esc key until the main menu CELL is on the screen.

2) Using the arrow keys, highlight the menu option SET_CMDS. Press the Enter key.

3) Press the function key F7 to bring up the summary screen. (This will blank out the menu area. The menu area will return when an arrow key is entered.)

4) For each subordinate workstation that is being used, perform the next 4 steps. (An example of shutting down the Cleaning and Deburring Workstation is shown.)

5) Using the arrow keys, highlight the menu option for the workstation desired (for this example use CDWS). Press the Enter key.

6) Using the arrow keys, highlight the menu option SHUTDOWN. Press the Enter key. See Figure 18.

7) Wait for the workstation to return a SHUTDOWN status. The COMPAQ's screen should look roughly like Figure 19 when the SHUTDOWN status has been returned.

8) Enter the Esc key to return to the SET_CMDS menu.

9) If there are more subordinate workstations to be shutdown, repeat steps 5 through 8 for each workstation.

10) Using the arrow keys, highlight the menu option EXIT. Press the Enter key. See Figure 20 for the menu portion of the EXIT screen.

11) Using the arrow keys, highlight the menu option YES. Press the Enter key.

12) The COMPAQ computer's prompt should return on the screen.

13) Turn off the power on the COMPAQ computer.

14) The cell controller is now shutdown. 


\section{APPENDIX FIGURES OF CELI SCREENS}

CELL

SET COMM SET CMDS SET STATS ORDERS TYPE SCREEN EXIT

COMM SWITCH COMM UNIT EXIT

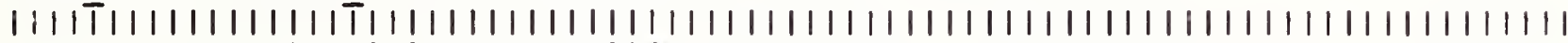

AMRF Cell Version 2.2 August 1987

CYCLE: 2 SCRN:STARTUP SYS:CDWS COMM:OFF TIME:16:08.49

CELL Menu

Figure 2 
ON OFF EXIT

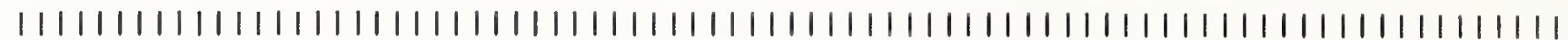
AMRF Cell Version 2.2 August 1987

CYCLE: 4 SCRN:STARTUP SYS:CDWS COMM:OFF TIME:13:39.18

\section{SET COMM Menu \\ $\bar{F}$ igure 3}

COMM SWITCH

ON OFF EXIT

$111 \mid 111111111111111111111111111111111111111111111111111111111111111111111111111$ AMRF Cell Version 2.2 August 1987

CYCLE: 
COMM_SWITCH

ON OFF EXIT

1111111111111111111111111111111111111111111111111111111111111111111111111111111 AMRE Cell Version 2.2 August 1987

CYCLE:

5 SCRN:STARTUP SYS:CDWS COMM:IDLE TIME:13:39.20

COMM SWITCH menu

$\bar{F}$ igure 5

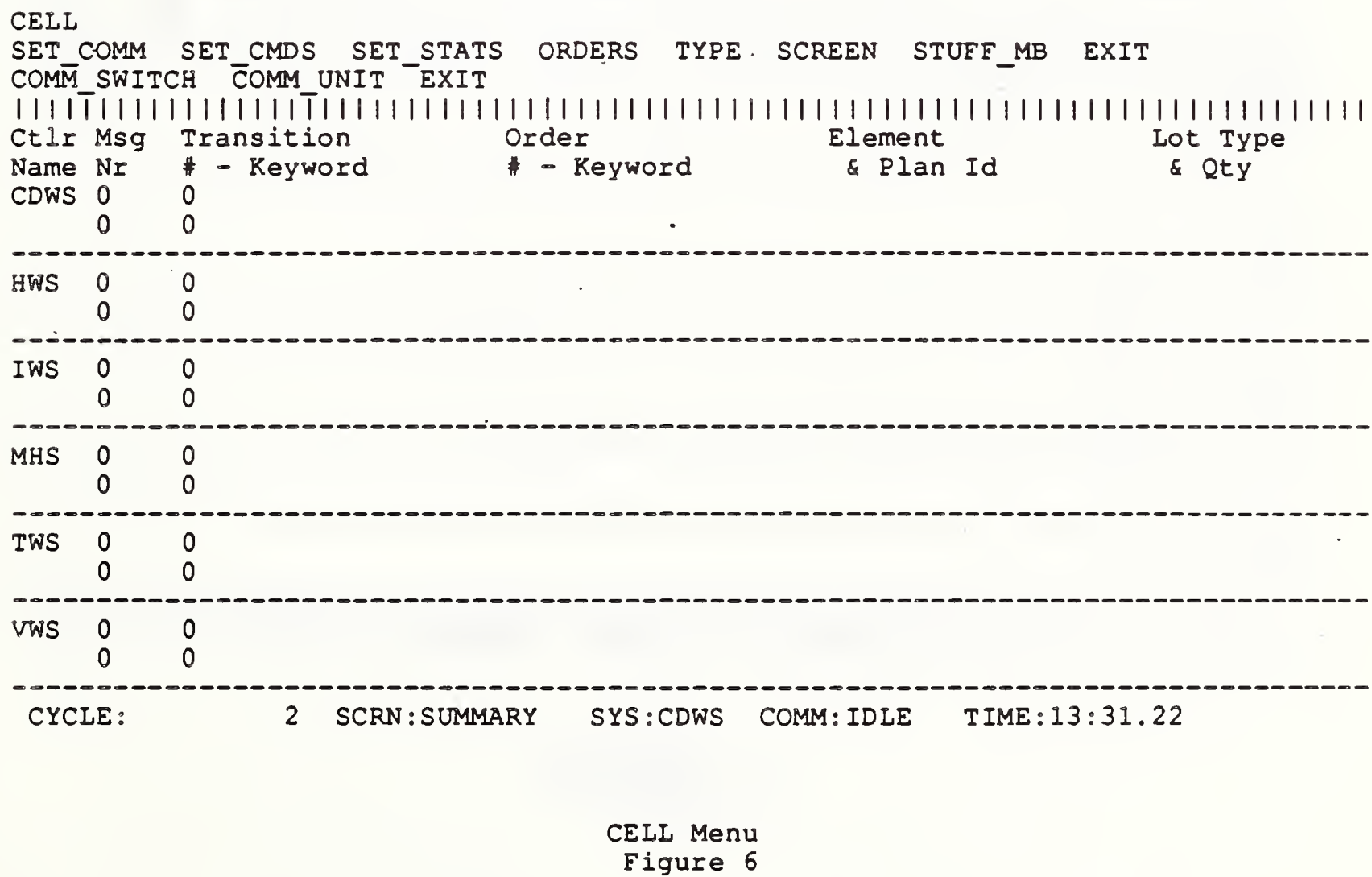




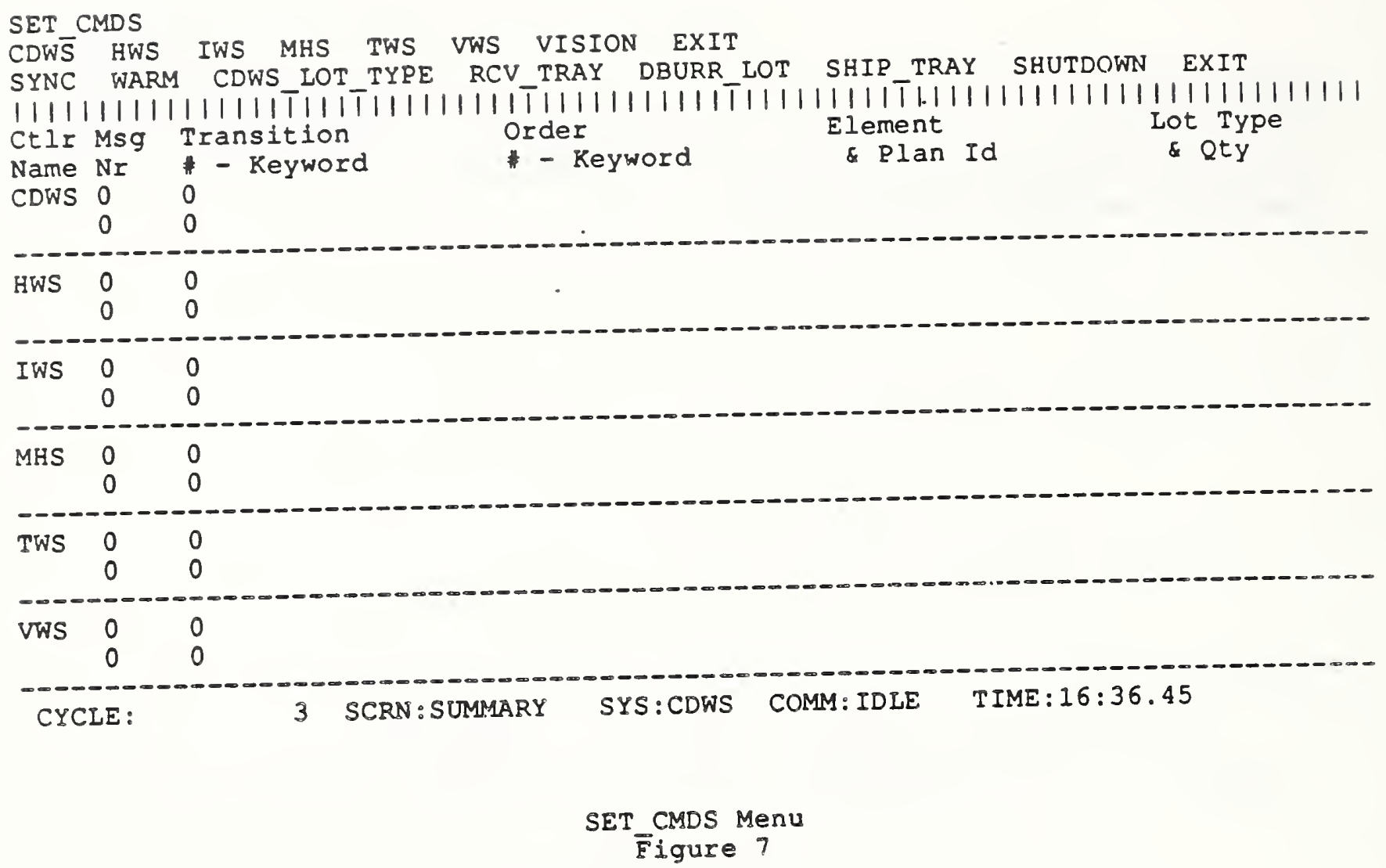

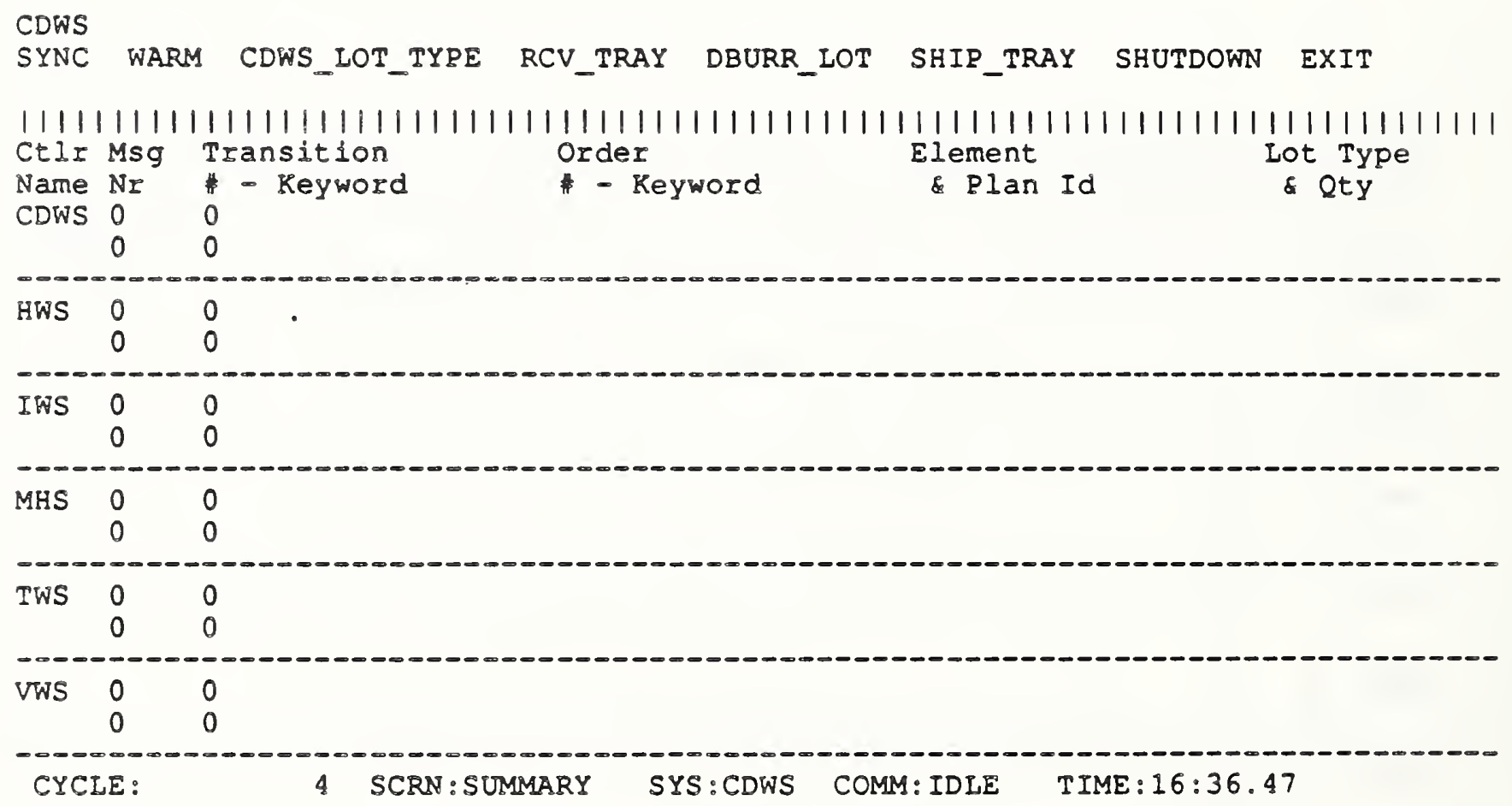

CDWS Menu

Figure 8 


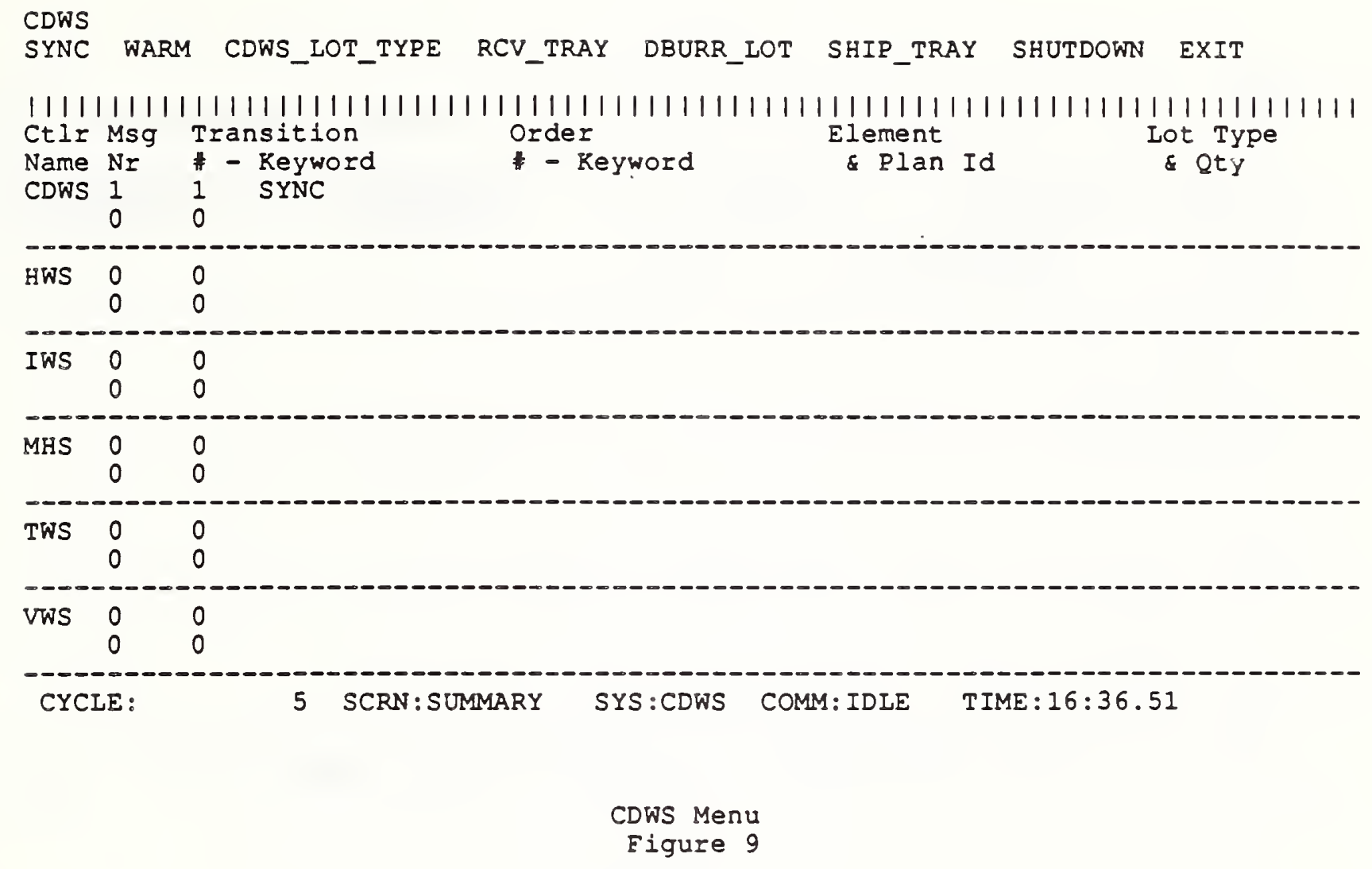

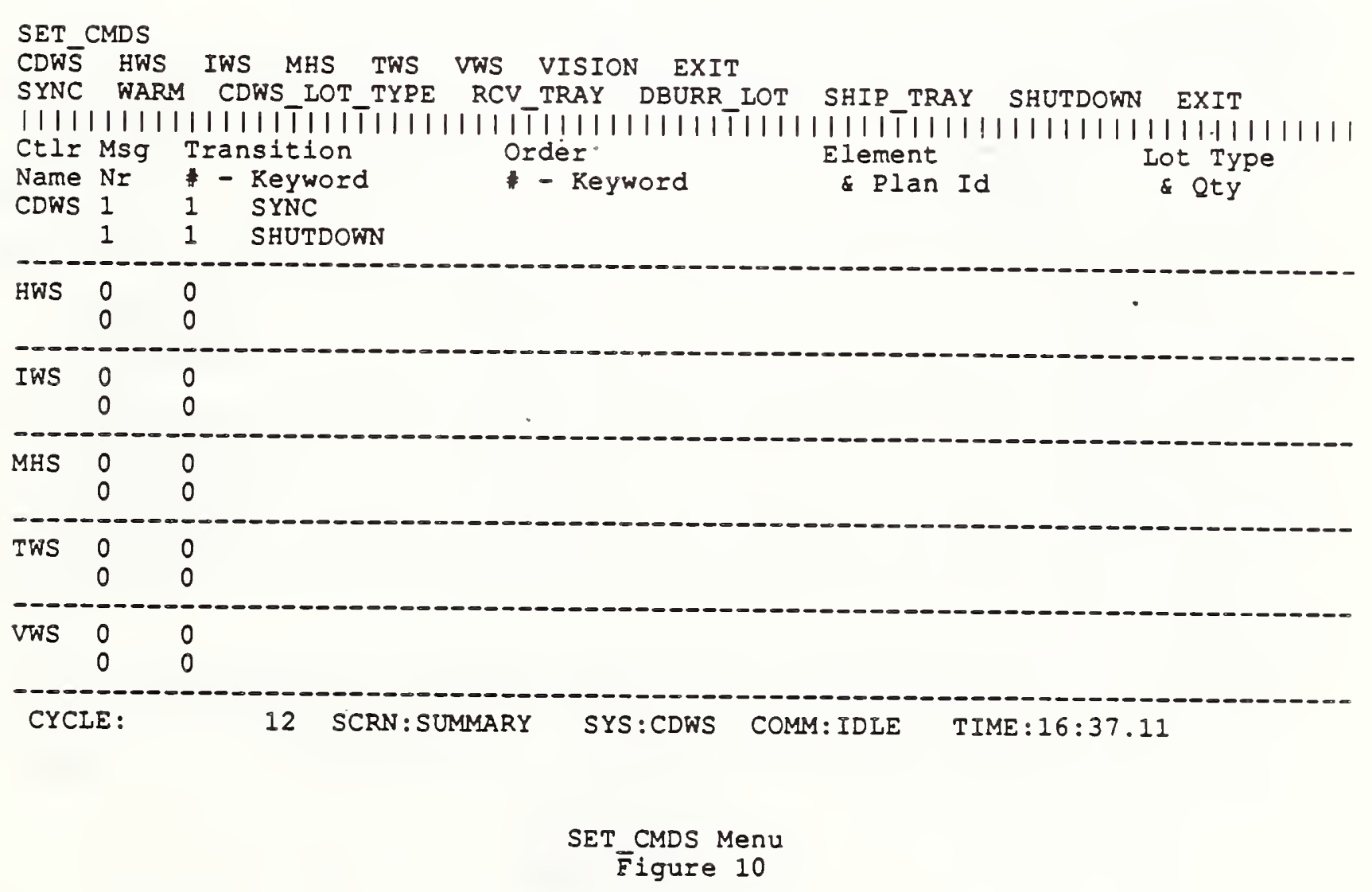




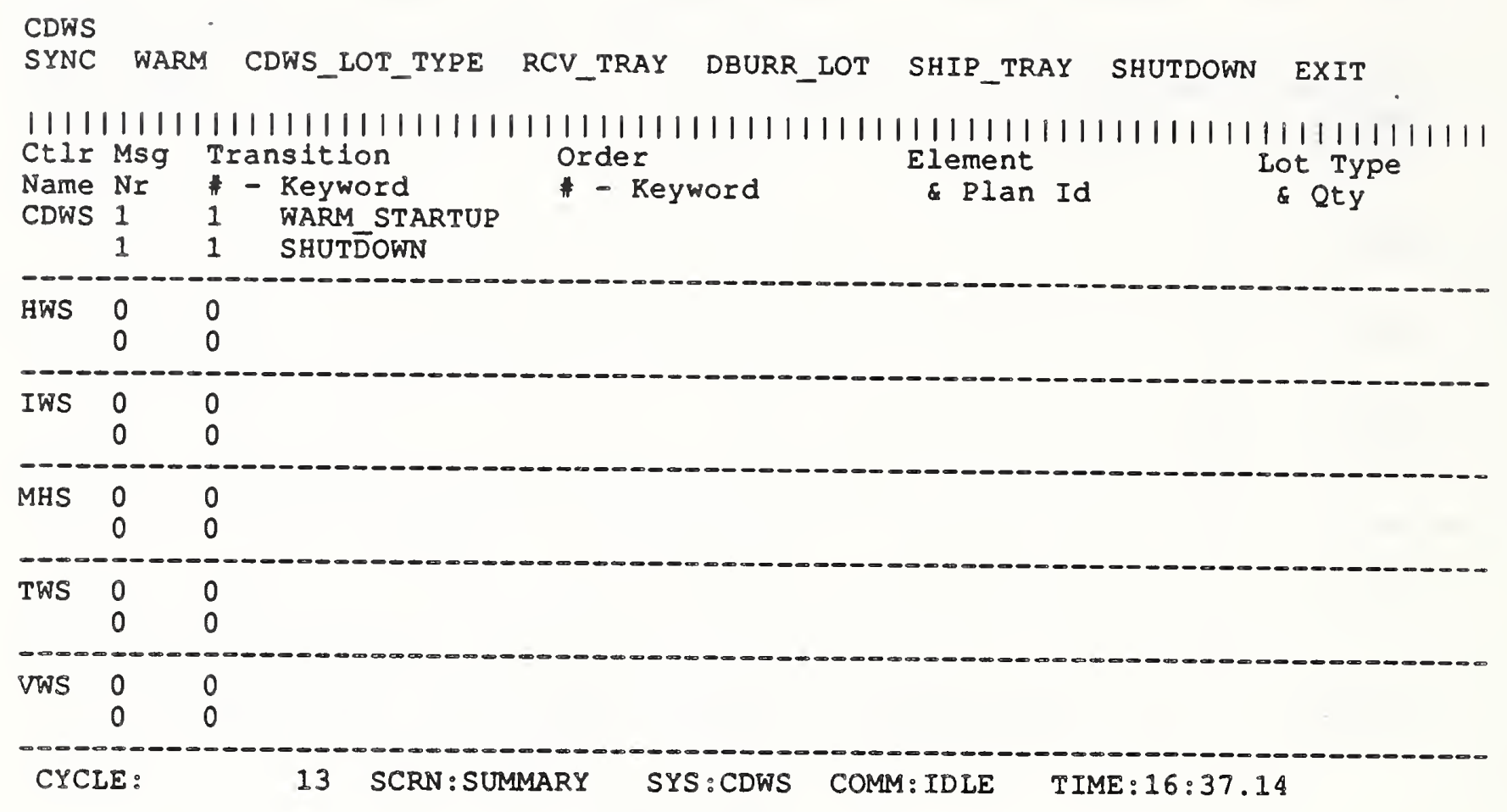

CDWS Menu

Figure 11

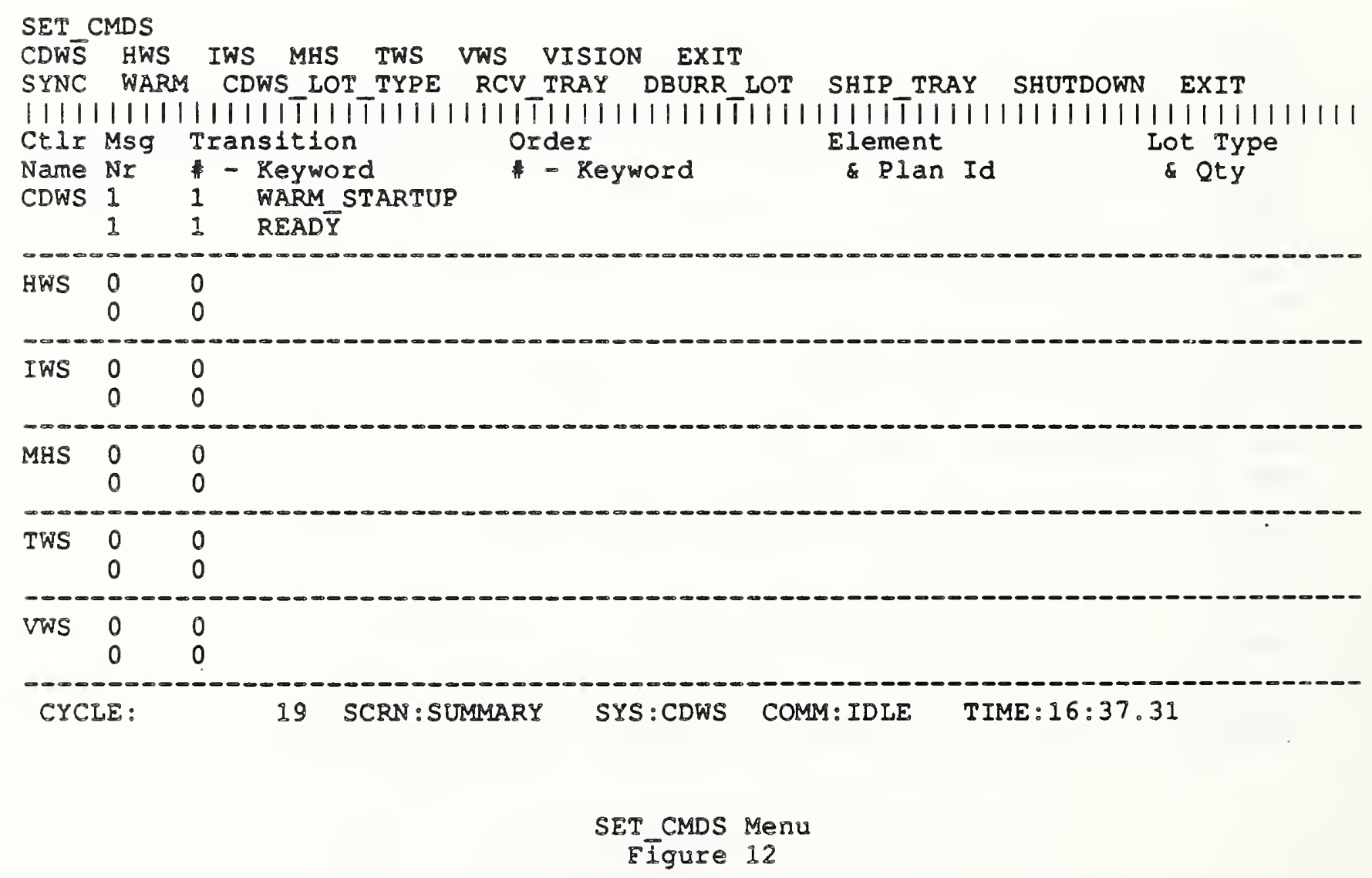


ORDERS

ENTRY STATUS HISTORY EXIT

111111111111111111111111111111111111111111111111111111111111111111111111111111 AMRF Cell Version 2.2 August 1987

CYCLE: $\quad 3$ SCRN:STARTUP SYS:CDWS COMM:IDLE TIME:16:11.50

- ORDERS Menu

Figure 13

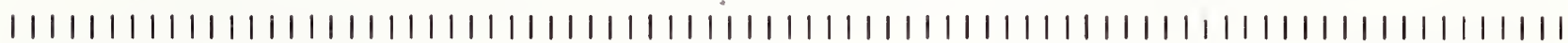
ORDER ENTRY

$\begin{aligned} \text { SEQ } & \text { PART_ID } \\ 1 & \text { MIXED_510 } \\ 2 & \text { MIXD_520 } \\ 3 & \text { MIXED_530 } \\ 4 & \text { DOG } \\ 5 & \text { LCLEVIS } \\ 6 & \text { BLOCK_FH } \\ 7 & \text { PIPECIAMP_FV } \\ 8 & \text { NIPPLE } \\ 9 & \text { SLBEARING } \\ 10 & \text { LCLEVIS }\end{aligned}$

BATCH_ID

IWS 510

IWS 520

IWS 530

CWS 400

CWS $^{-} 440$

$\mathrm{CWS}^{-} 410$

CWS 430

TWS 303

TWS 305

VWS_200
FILE.

PLAN5

PLAN22

PLAN6

PLAN20

PLAN21

PLAN7

PLAN8

PLAN19

PP CELI 183

PLĀN10

\footnotetext{
CYCLE: 3 SCRN:SEQS SYS:CDWS COMM:IDLE TIME:16:11.51

ORDER ENTRY SCIEen

Figure 14
} 


\begin{tabular}{|c|c|c|c|}
\hline SEQ & PART_ID & BATCH_ID & FIIE \\
\hline 1 & MIXED 510 & IWS 510 & PLAN5 \\
\hline 2 & MIXED-520 & IWS 520 & PLAN22 \\
\hline 3 & MIXED ${ }^{-} 530$ & IWS $^{-} 530$ & PLAN6 \\
\hline 4 & DOG - & $\mathrm{CWS}^{-} 400$ & PLAN20 \\
\hline 5 & LCLEVIS & CWS 440 & PLAN21 \\
\hline 6 & BLOCK FH & $\mathrm{CWS}^{-} 410$ & PLAN 7 \\
\hline 7 & PIPEC $\bar{L} A M P$ FV & $\mathrm{CWS}^{-} 430$ & PLAN8 \\
\hline 8 & NIP?LE - & TWS 303 & PLAN19 \\
\hline 9 & SLBEARING & TWS 305 & PP CELL 183 \\
\hline 10 & LCLEVIS & WWS 200 & $\mathrm{PL} \overline{\mathrm{A} N} 10$ \\
\hline
\end{tabular}

ORDER ACCEPTED

CYCLE: SCRN:SEQS SYS:CDWS COMM:IDLE TIME:15:14.42

ORDER ENTRY Screen

Figure 15

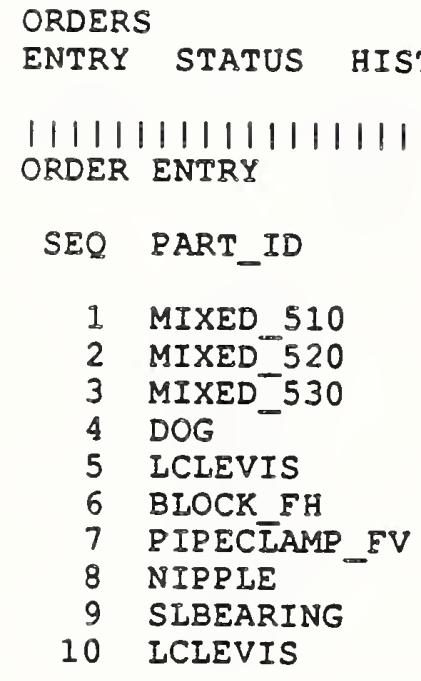

CYCLE: 


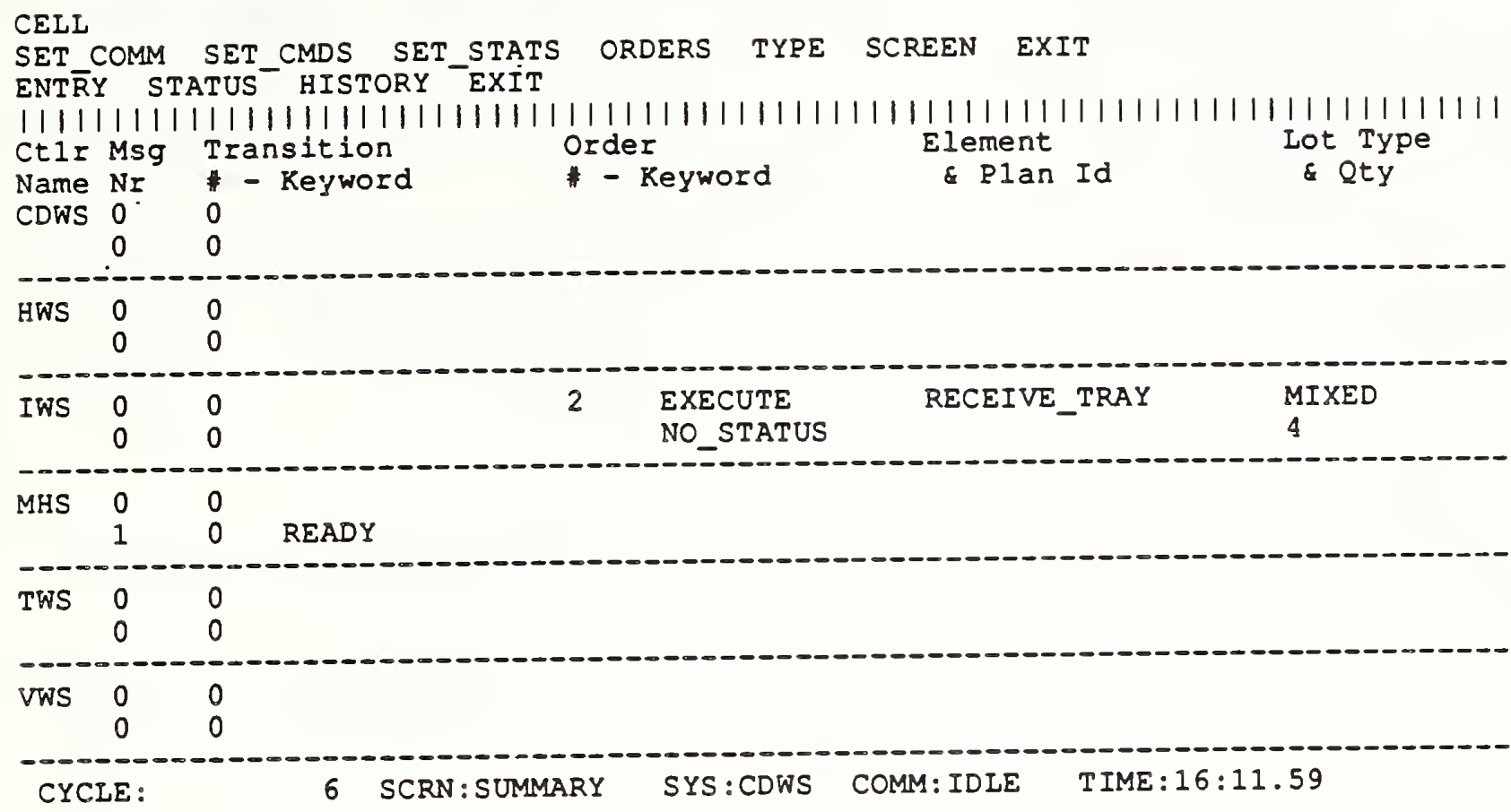

CELL Menu

Figure 17

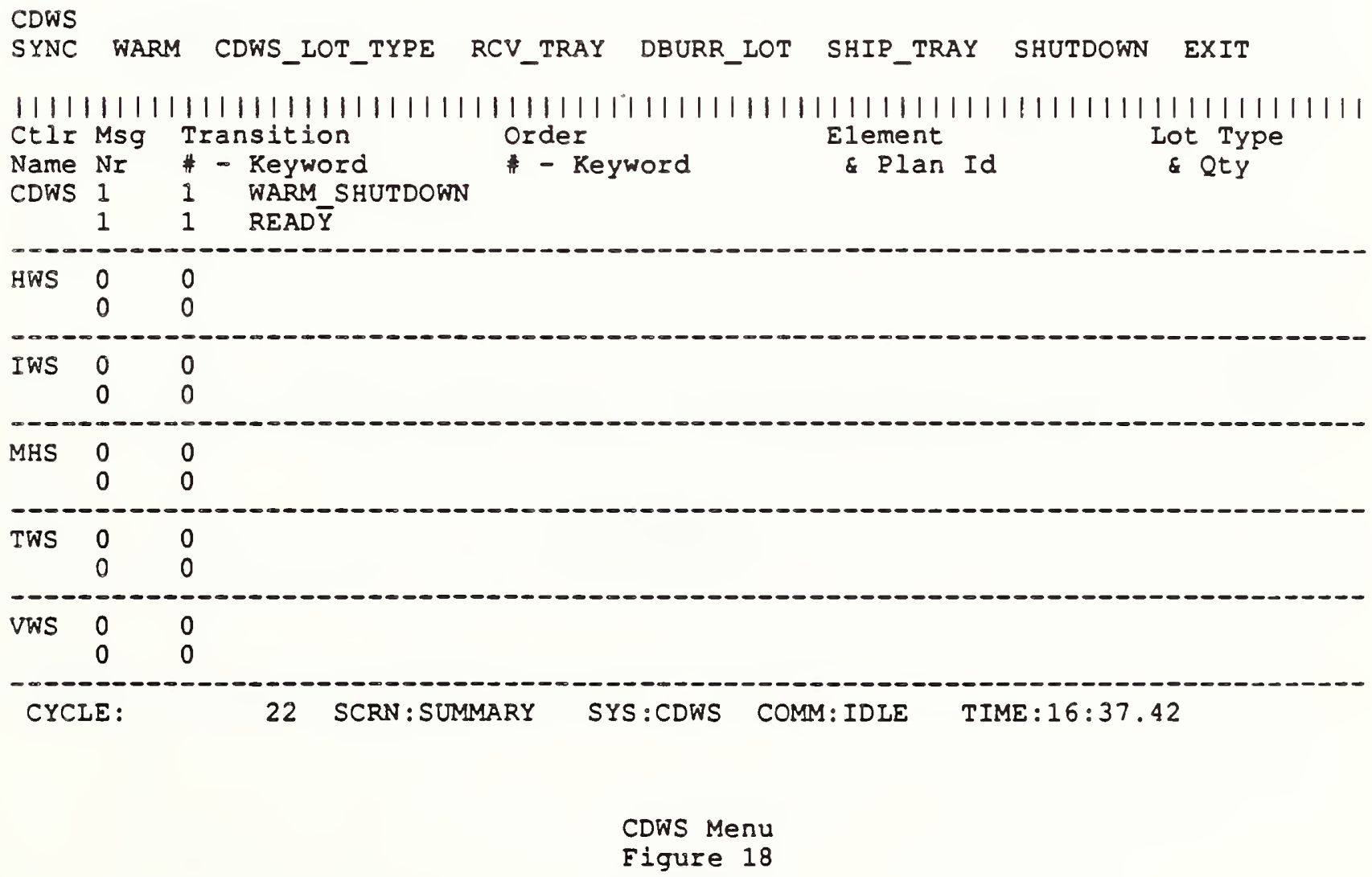




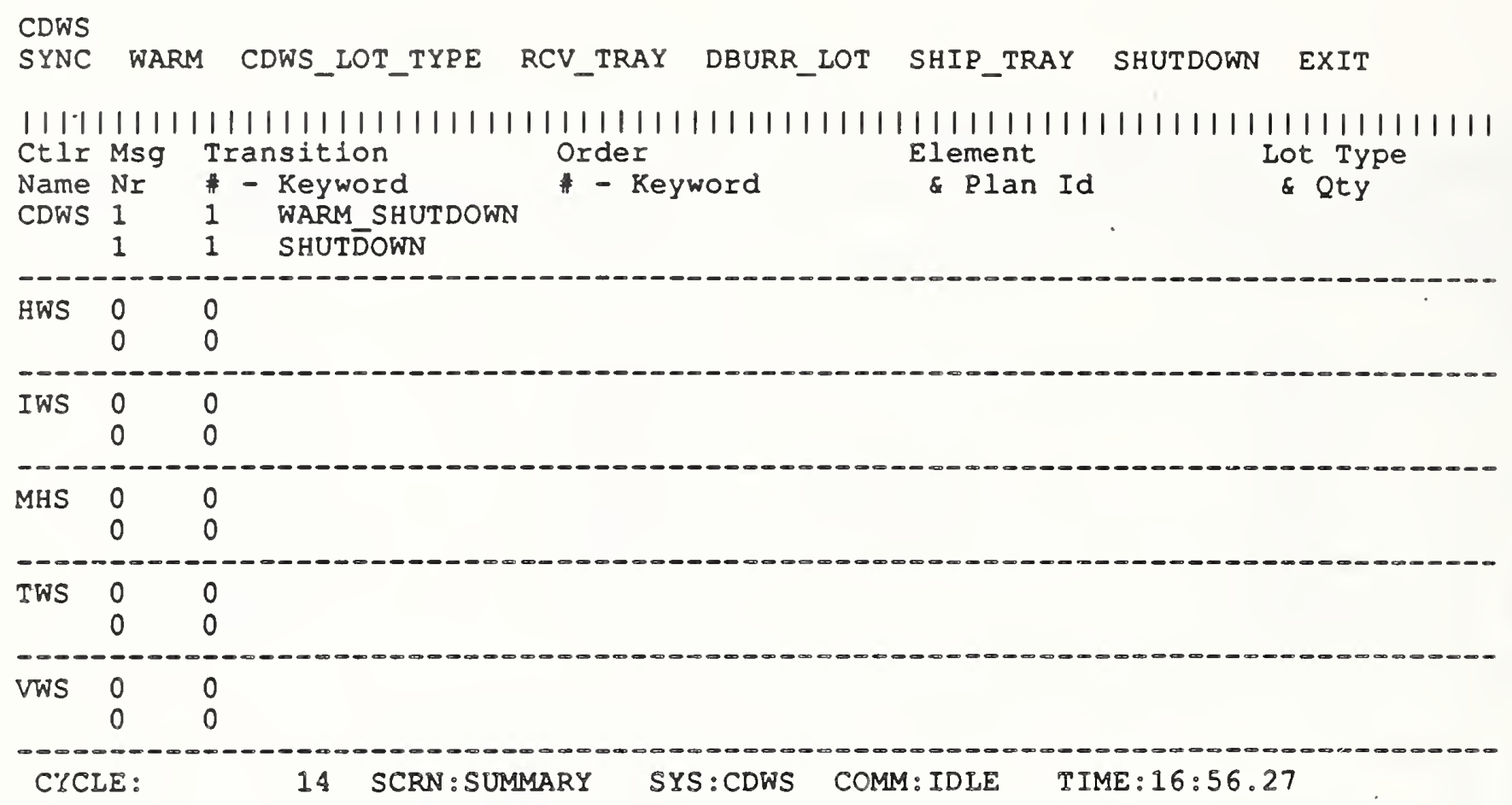

CDWS Menu

Figure 19

EXIT

YES NO

111111111111111111111111111111111111111111111111111111111111111111111111111111

ExIT Menu

Eigure 20 


\section{BIBLIOGRAPHY}

1. Albus, J. A., AMRF Architectural Principles, to be published as an NBSIR, 1988.

2. Mclean, C. R., principles of the cell control system, to be published as an NBSIR, 1988.

3. Mclean, C. R., Implementation of the cell control system, to be published as an NBSIR, 1988.

4. O'Halloran, D. R., Reynolds, P. F., A Model for AMRF Initialization, Restart, Reconfiguration, and Shutdown, May 23, 1986, NBS/GCR 88-546. 



\section{READER COMMENT FORM}

Document Title Cell Controller Users Guide by Bruce Hunter Thomas

This document is one in a series of publications which document research done at the National Bureau of Standards' Automated Manufacturing Research Facility from 1981 through March, 1987.

You may use this form to comment on the technical content or organization of this document or to contribute suggested editorial changes.

comments:

If you wish a reply, give your name, company, and complete mailing address:

What is your occupation?

NOTE: This form may not be used to order additional copies of this document or other documents in the series. Copies of AMRF documents are available from NTIS.

Please mail your comments to: AMRF Program Manager National Bureau of Standards Building 220, Room B-111 Gaithersburg, MD 20899 

NBS-114A (REV. 2.8C)

U.S. DEPT. OF COMM.

1. PUBLICATION OR REPORT NO.

BIBLIOGRAPHIC DATA

SHEET (See instructions)
2. Performing Organ. Report No. 3. Publication Date

MAY 1988

4. TITLE AND SUBTITLE

Cell Controller Operations Manual

\section{5. $A \cup T H O R(S)$}

Bruce H. Thomas

6. PERFORMING ORGANIZATION (If joint or other than NBS, see instructions)

7. Contrace/Grant No.

NATIONAL BUREAU OF STANDARDS

DEPARTMENT OF COMMERCE

WASHINGTON, D.C. 20234

9. SPONSORING ORGANIZATION NAME AND COMPLETE ADDRESS (Street, Gity. Stote, ZIP)

8. Type of Report \& Period Covered

10. SUPPLEMENTARY NOTES

Document describes a computer program; SF-185. FIPS Software Summary, is attached.

11. ABSTRACT (A 200-word or less factual summary of most significant information. If document includes a significant bibliography or literature survey, mention it here)

This manual is designed to show a novice user how to startup, operate, and shutdown the cell controller. The manual assumes the operator knows the basic operation of a PC-clone computer. There are four major sections to this manual, basic operation of the cell screen management system, startup of the cell, operation of the cell, and shutdown of the cell.

12. KEY WORDS (Six to twelve entries; alphobetical order: capitalize only proper names: and separate key words by semicolons) Cell control, user's manual, manufacturing, AMRF

13. AVAILABILITY

X Unlimited

For Official Distribution. Do Not Release to NTIS

Order From Superintendent of Documents, U.S. Government Printing Office, Washingron. D.C. 20402.

[X] Order From National Technical Information Service (NTIS), Springfield, VA. 22161
14. NO. OF PRINTED PAGES

22

15. Price

$\$ 9.95$ 


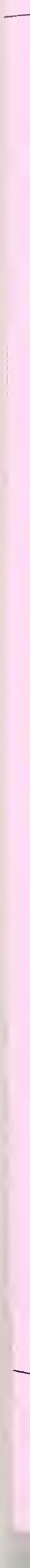

